\title{
Pengembangan Animasi Dua Dimensi Pada Pembelajaran Tematik Untuk Siswa Kelas III Sekolah Dasar
}

\author{
Yunia Isni Siddiq \\ Program Studi Teknologi Pendidikan, Universitas Pendidikan Ganesha \\ yunia.isni.siddiq@undiksha.ac.id \\ I Komang Sudarma \\ Program Studi Teknologi Pendidikan, Universitas Pendidikan Ganesha \\ iksudarma@undiksha.ac.id
}

\author{
Alexander Hamonangan Simamora \\ Program Studi Teknologi Pendidikan, Universitas Pendidikan Ganesha \\ alexander.simamora@undiksha.ac.id
}

\author{
A R T I C L E I N F O \\ Article history: \\ 1 Juli 2020 Received in \\ revised form \\ 30 Agustus 2020 \\ Accepted 28 September 2020 \\ Available online \\ 30 September 2020

\section{Kata Kunci: \\ Animasi dua dimensi, \\ tematik, ADDIE}

\section{Keywords:} \\ two-dimensional animation, \\ thematic, ADDIE
}

\begin{abstract}
ABSTRAK
Penelitian pengembangan ini dilatarbelakangi oleh rendahnya hasil belajar tematik siswa, yang disebabkan karena kurangnya media pembelajaran tematik untuk memfasilitasi siswa dalam belajar. Penelitian ini bertujuan untuk mendeskripsikan rancang bangun animasi dua dimensi, dan mendeskripsikan kualitas hasil validasi animasi dua dimensi. Model yang digunakan dalam penelitian pengembangan ini adalah model ADDIE. Metode yang digunakan dalam pengumpulan data yaitu wawancara, pencatatan dokumen, observasi dan kuesioner. Hasil penelitian (1) rancang bangun animasi dua dimensi pada pembelajaran tematik meliputi lima tahapan, yaitu: analisis, desain, pengembangan,
\end{abstract} implementasi, dan evaluasi. (2) hasil uji validasi yang dilakukan oleh para ahli dan subyek uji coba produk menunjukkan bahwa animasi dua dimensi pada pembelajaran tematik valid berdasarkan: (a) hasil review ahli isi pembelajaran dengan kualifikasi sangat baik $(94,5 \%)$, (b) hasil review ahli desain pembelajaran dengan kualifikasi sangat baik (95\%), (c) hasil review ahli media pembelajaran dengan kualifikasi sangat baik (95\%), (d) hasil uji coba perorangan dengan kualifikasi sangat baik $(90,91 \%)$, (e) dan hasil uji coba kelompok kecil dengan kualifikasi sangat baik $(92,42 \%)$. Jadi, penelitian menunjukkan bahwa animasi dua dimensi berada pada kualifikasi sangat baik. 


\section{PENDAHULUAN}

Perkembangan teknologi informasi dan komunikasi yang semakin pesat telah membawa dampak yang sangat berguna bagi kehidupan manusia. Kehadiran teknologi informasi dan komunikasi telah membantu kegiatan masyarakat dalam berbagai aspek kehidupan seperti politik, budaya, sosial, ekonomi, dan pendidikan. Berkembangnya teknologi informasi dan komunikasi menuntut dunia pendidikan untuk selalu senantiasa menyesuaikan perkembangan teknologi guna meningkatkan kualitas pendidikan, terutama dalam proses pembelajaran (Budiman, 2017). Dalam mencapai tujuan pendidikan, penyelenggaraan pendidikan disesuaikan dengan perkembangan dan perubahan yang terjadi saat ini. Adanya bukti perubahan dalam menyesuaikan perkembangan zaman ialah perubahan kurikulum, yang sebelumnya menggunakan Kurikulum Tingkat Satuan Pendidikan (KTSP) telah diubah menjadi Kurikulum 2013. Kurikulum 2013 merupakan penyempurnaan dari kurikulum sebelumnya yaitu Kurikulum Tingkat Satuan Pendidikan. Kristiantari (dalam Astiningtyas, 2018:61) mengungkapkan bahwa "kurikulum 2013 memiliki tujuan untuk mendorong siswa memiliki pengalaman belajar dalam prinsip 5M yaitu mengamati, menanya, mencari informasi, mengasosiasi, dan mengkomunikasikan apa yang telah diperoleh setelah menerima materi”. Tema pembaharuan pada Kurikulum 2013 ini adalah ingin menciptakan manusia Indonesia yang mampu berpikir kreatif, produktif, inovatif, proaktif, afektif, melalui pengembangan sikap, keterampilan, dan pengetahuan secara integratif (Mastur, 2017).

Pembelajaran tematik merupakan salah satu gagasan dalam kurikulum 2013, hal ini sesuai dengan peraturan Menteri Pendidikan dan Kebudayaan No. 67 Tahun 2013 yang menjelaskan bahwa Kurikulum 2013 pada jenjang Sekolah Dasar/Madrasah Ibtidaiya didesain menggunakan pembelajaran tematik-terpadu mulai dari kelas I sampai dengan kelas VI. Prameswari (2017) mengatakan bahwa pembelajaran tematik merupakan pendekatan pembelajaran yang memadukan beberapa kompetensi dasar dari beberapa mata pelajaran menjadi satu kesatuan untuk dikemas dalam satu tema. Prastowo (2014:56) juga berpendapat bahwa, siswa harus aktif terlibat dalam pembelajaran dan pemberdayaan memecahkan masalah, sehingga dapat menumbuhkan kreativitas dan potensi yang dimiliki oleh siswa. Terdapat tiga hal yang harus dipersiapkan dalam pembelajaran tematik yaitu, penyusunan perencanan pembelajaran, penerapan atau pelaksanaan pembelajaran, dan evaluasi pembelajaran tematik (Pratiwi dan Widagdo, 2017). Untuk itu, meningkatkan kualitas pendidikan diperlukan upaya perencanaan pembelajaran yang baik.

Namun kenyataannya, saat ini masih banyak pengajar yang menerapkan pembelajaran secara konvensional yang berdampak pada hasil belajar siswa. Dalam pembelajaran konvensional, aspek verbal sering digunakan dalam metode pembelajaran guru yang dominan dilakukan dengan ceramah dalam menyampaikan materi pembelajaran (Kustandi, dan Darmawan, 2020). Hal tersebut juga terjadi di SD Negeri 1 Banjar Bali. Berdasarkan hasil wawancara dengan guru pengajar pembelajaran tematik kelas III, kendala utama yang ditemukan yaitu kurangnya media untuk mendukung materi pembelajaran tematik yang memadukan beberapa mata pelajaran dalam memfasilitasi siswa dalam belajar. Selain itu, konsep materi pembelajaran tematik sulit dipahami oleh siswa. Hal ini dikarenakan konsep materi pembelajaran tematik bersifat abstrak. Berdasarkan hasil observasi yang dilakukan pada PPL Real TP yang dilaksanakan pada semester ganjil tahun akademik 2018/2019 di SD Negeri 1 Banjar Bali, bahwa guru cenderung menggunakan metode pembelajaran ceramah, diskusi, dan tanya jawab. Bahan 
ajar yang digunakan buku paket dan terkadang menggunakan media power point disesuaikan dengan materi pelajaran yang disampaikan. Selama proses pembelajaran di kelas, sekitar kurang lebih 8 dari 29 orang siswa yang aktif bertanya maupun menjawab pertanyaan. SD Negeri 1 Banjar Bali memiliki fasilitas berupa LCD Proyektor, dan sound siystem, namun jarang dimanfaatkan dalam kegiatan pembelajaran. Berdasarkan analisis yang dilakukan hasil belajar tematik yang dicapai siswa kelas III SD Negeri 1 Banjar Bali pada semester ganjil 2018/2019 dengan jumlah siswa sebanyak 29 orang, di beberapa mata pelajaran masih belum memenuhi kreteria ketuntasan minimal (KKM). Hasil kuesioner yang diberikan kepada siswa kelas III di SD Negeri 1 Banjar Bali, menyatakan bahwa: (1) $72,41 \%$ siswa atau 201 dari 29 orang siswa lebih senang belajar menggunakan media audio visual daripada menggunakan media cetak (LKS, modul, dll). (2) 72,41\% siswa atau 21 dari 29 orang siswa lebih mudah memahami pelajaran setelah guru menggunakan media pembelajaran. (3) $57,17 \%$ atau 16 dari 29 orang siswa merasa bosan jika kegiatan belajar tidak menggunakan media pembelajaran, dan (4) sekitar 86,2\% siswa atau 25 dari 29 orang siswa lebih terbantu memahami materi setelah guru menggunakan media pembelajaran.

Berdasarkan permasalahan tersebut, salah satu solusi yang ditawarkan yaitu dengan mengembangkan media pembelajaran animasi dua dimensi. Animasi dua dimensi ini, didesain untuk mempermudah siswa dalam memahami materi pembelajaran tematik, serta mambantu guru dalam menyampaikan materi pembelajaran. Hal ini dikarenakan animasi dua dimensi yang dikembangkan disesuaikan dengan karakteristik siswa, serta pada animasi dua dimensi terdapat komponen teks, audio, visual, musik, dan sound $f x$ untuk menarik perhatian siswa dalam belajar, sehingga dapat meningkatkan hasil belajar siswa. Selain itu, terdapat evaluasi untuk mengetahui tingkat pengetahuan kognitif siswa setelah menggunakan media pembelajaran animasi dua dimensi. Penelitian pengembangan ini didukung oleh penelitian yang sudah ada sebelumnya, yaitu hasil penelitian yang dilakukan oleh Wahyuni, dkk (2018:27) yang mengungkapkan bahwa animasi berpengaruh signifikasi terhadap peningkatan berfikir kritis siswa dan aktivitas belajar siswa pada materi pembelajaran larutan elektronik dan nonelektronik. Kasih (2017) juga mengungkapkan bahwa animasi efektif meningkatkan hasil belajar siswa pada pembelajaran fisika. Pratama, dkk (2020:15) juga mengungkapkan bahwa video animasi pembelajaran efektif dalam meningkatkan pemahaman siswa terhadap pembelajaran budaya Reog Ponorogo. Widjayanti (2019) juga mengungkapkan bahwa setelah menggunakan animasi, sebanyak $87,50 \%$ siswa tuntas belajar. Selain itu, animasi juga dapat meningkatkan minat siswa dan sangat praktis digunakan dalam pembelajaran. Awalia, dkk (2019) dalam penelitiannya juga mengungkapkan bahwa penggunaan animasi dapat meningkatkan pemahaman siswa pada mata pelajaran matematika, dan dapat menarik perhatian siswa dalalm belajar. Berdasarkan hasil penelitian tersebut, dapat disimpulkan bahwa media pembelajaran animasi dapat mempermudah proses kegiatan pembelajaran dan dapat meningkatkan hasil belajar siswa.

Animasi merupakan kumpulan beberapa gambar yang kemudian diolah sedemikian rupa sehingga mendapatkan gerakan (Delen dalam Muzakki, dkk 2016). Dalam pengembangannya, animasi dikerjakan menggunakan teknik tertentu sehingga gambar diam terebut seolah-olah memiliki nyawa atau hidup. Rosmiati (2019) mengatakan bahwa animasi dalam pembelajaran memiliki peran yang dapat meningkatkan minat belajar, meningkatkan pemahaman terhadap suatu bidang ilmu tertentu, dan mempermudah guru dalam proses pembelajarn. Animasi memiliki beberapa kelebihan, yaitu: dapat menarik 
perhatian, (2) dapat memperjelas suatu ilustrasi dari konsep yang sulit dan berbahaya, dan (3) dapat menjadi media komunikasi audio visual yang dahsyat dalam mengembangkan simbol-simbol visual atau auditif dalam menyampaikan suatu informasi (Aziz, 2019).

Herlyani (2014) mengungkapkan bahwa terdapat beberapa jenis animasi, diantaranya: animasi dua dimensi/classic animation, animasi tiga dimensi/digital animation, dan stop motion/clay animation. Menurut Binanto (2010) animasi dua dimensi merupakan suatu teknik yang dibuat/diedit di komputer menggunakan vector dua dimensi Istilah animasi dua dimensi yaitu salah satu teknik pembuatannya menggunakan perangkat lunak komputer. Mulai dari membuat satu gambar, proses pewarnaan, mengatur gerak, dan mengatur waktu. Disebut dua dimensi karena hanya memiliki dua sisi saja, sisi lebar dan sisi panjang serta tidak ada unsur ketebalan. Penelitian yang dilakukan oleh Jembari, dkk (2015) mengungkapkan bahwa animasi dua dimensi efektif meningkatkan hasil belajar. Selain itu, animasi dua dimensi juga mendukung pembelajaran yang inovatif dan menyenangkan.

Berdasarkan permasalahan di atas, media pembelajaran inovatif yang dapat membantu siswa belajar sangat diperlukan sehingga dilakukan pengembangan media animasi dua dimensi pembelajaran tematik untuk Sekolah Dasar. Tujuan penelitian ini yaitu untuk mendeskripsikan rancang bangun animasi dua dimensi dan mendeskripsikan validitas pengembangan animasi dua dimensi. Animasi dua dimensi dipilih karena animasi memiliki kemampuan untuk dapat menjelaskan suatu konsep yang rumit dan sulit menjadi menarik secara visual dan juga dinamik Suartama (2017:14). Penelitian pengembangan animasi dua dimensi ini diharapkan dapat memfasilitasi siswa dalam belajar, meningkatkan motivasi siswa, mudah memahami materi pelajaran, serta meningkatkan hasil belajar siswa.

\section{METODE PENELITIAN}

Penelitian pengembangan ini dilaksanakan pada 06 Januari 2020 sampai 23 Juli 2020. Subjek penelitian ini yaitu: 1 ahli desain pembelajaran, 1 ahli media pembelajaran, 2 ahli isi pembelajaran, 3 orang untuk uji coba perorangan, dan 6 orang untuk uji coba kelompok kecil. Prosedur pengembangan yang digunakan dalam penelitian ini menggunakan model ADDIE. Tegeh dan Jampel (2017:79) mengemukakan bahwa tahapan model ADDIE terdiri atas lima tahapan, yaitu: “(1) Analisis (Anlayze), (2) Perancangan (Design), (3) Pengembangan (Development), (4) Implementasi (Implementation), dan (5) evaluasi (evaluation)".

Pengumpulan data dalam penelitian pengembangan ini menggunakan metode pencatatan dokumen, wawancara, observasi, dan kuesioner. Metode pencatatan dokumen merupakan cara mendapatkan data melalui pengumpulan berbagai jenis dokumen dan melakukan pencatatan secara sistematis (Agung, 2017). Dokumen yang dikumpulkan adalah nilai UTS semester ganjil tahun 2018/2019 siswa kelas III SD Negeri 1 Banjar Bali dan juga RPP (Rencana Pelaksanaan Pembelajaran). Wawancara merupakan cara mendapatkan informasil melalui tanya jawab yang sistematis yang direkam atau dicatat secara cermat (Agung (2017). Wawancara digunakan untuk mengumpulkan data mengenai masalah pembelajaran yang terjadi di lapangan. Observasi merupakan cara yang dilakukan untuk mendapatkan data melalui pengamatan secara langsung di lapangan, Nurkanca (dalam Agung, 2017). Observasi dilakukan untuk mengumpulkan data mengenai permasalahan yang ada, seperti observasi lingkungan sekolah dan kegiatan pembelajaran siswa. Metode kuesioner merupakan cara mendapatkan informasi yang dilakukan dengan 
mengirimkan suatu pertanyaan kepada responden penenelitian untuk dijawab secara tertulis (Agung, 2017). Metode kuesioner digunakan untuk mengetahui karakteristik siswa, mengukur kelayakan produk yang dikembangkan dari ahli isi pembelajaran, ahli desain pembelajaran, uji coba perorangan, dan uji coba kelompok kecil. Adapun kisi-kisi instrumen ahli desain pembelajaran dalam penelitian ini dapat disajikan pada tabel 1.

Tabel 1. Kisi-kisi Instrumen Ahli Desain Pembelajaran

\begin{tabular}{|c|c|c|c|}
\hline No & Aspek & Indikator & $\begin{array}{c}\text { Jumlah } \\
\text { Butir }\end{array}$ \\
\hline 1 & Media & $\begin{array}{l}\text { a. Kejelasan judul animasi } \\
\text { b. Kejelasan sasaran pengguna }\end{array}$ & 2 \\
\hline 2 & Tujuan & $\begin{array}{l}\text { a. Kesesuaian indikator dengan kompetensi dasar } \\
\text { b. Kesesuaian tujuan pembelajaran dengan rumusan } \\
\text { indikator dan kompetensi dasar } \\
\text { c. Kesesuaian tujuan pembelajaran dengan format } \\
\text { ABCD }\end{array}$ & 3 \\
\hline 3 & Strategi & $\begin{array}{l}\text { a. Ketepatan cara penyajian materi } \\
\text { b. Penggunaan ilustrasi/contoh } \\
\text { c. Pemberian umpan balik } \\
\text { d. Memicu ketertarikan dan keterlibatan sasaran } \\
\text { belajar menggunakan animasi } \\
\text { e. Kesesuaian penyajian materi dengan karakteristik } \\
\text { sasaran }\end{array}$ & 5 \\
\hline 4 & Evaluasi & $\begin{array}{l}\text { a. Petunjuk pengerjakan soal } \\
\text { b. Kesesuaian soal dengan materi }\end{array}$ & 2 \\
\hline
\end{tabular}

Sumber: (Sanjaya, 2015)

Kisi-kisi instrumen ahli media pembelajaran dalam penelitian pengembangan animasi dua dimensi ini dapat disajikan pada tabel 2.

Tabel 2. Kisi-kisi Instrumen Ahli Media Pembelajaran

\begin{tabular}{|c|c|c|c|}
\hline No & Aspek & Indikator & $\begin{array}{c}\text { Jumlah } \\
\text { Butir }\end{array}$ \\
\hline 1 & Tampilan & $\begin{array}{l}\text { a. Ketepatan ukuran dan jenis huruf } \\
\text { b. Kejelasan gambar } \\
\text { c. Kejelasan penggunaan audio } \\
\text { d. Kejelasan animasi } \\
\text { e. Kemenarikan pengemasan media }\end{array}$ & 18 \\
\hline 2 & Aksesibilitas & $\begin{array}{l}\text { a. Kemudahan pengguna } \\
\text { b. Kelancaran link/tombol navigasi }\end{array}$ & 2 \\
\hline
\end{tabular}

Kisi-kisi instrumen ahli isi pembelajaran dalam penelitian pengembangan animasi dua dimensi ini dapat disajikan pada tabel 3.

Tabel 3. Kisi-kisi Instrumen Ahli Isi Pembelajaran

\begin{tabular}{cllc}
\hline No & Aspek & \multicolumn{1}{c}{ Indikator } & $\begin{array}{c}\text { Jumlah } \\
\text { Butir }\end{array}$ \\
\hline 1 & Struktur & a. Kesesuaian materi dengan kompetensi dasar & 3 \\
& Materi & b. Kesesuaian materi dengan indikator pembelajaran &
\end{tabular}


2 Isi Materi

c. Cakupan materi sesuai dengan cakupan tujuan pembelajaran

a. Kejelasan penyajian materi

b. Penggunaan ilustrasi/contoh yang relevan

c. Kesesuaian gambar untuk memperjelas materi pembelajaran

d. Kelengkapan penyajian materi

e. Pemberian umpan balik

3 Bahasa

a. Penggunaan kalimat pada animasi

b. Kesesuaian penggunaan bahasa dengan peserta didik

$4 \quad$ Evaluasi

a. Petunjuk pengerjaan soal

b. Pemberian soal relevan

Sumber: Alessi dan Trolip, 2011 (dalam Yogiyatno dan Soyan, 2013)

Kisi-kisi instrumen uji coba perorangan uji dan coba kelompok kecil dalam penelitian pengembangan animasi dua dimensi ini dapat disajikan pada tabel 4 .

Tabel 4. Kisi-kisi Instrumen Uji Coba Perorangan dan Kelompok Kecil

\begin{tabular}{|c|c|c|c|}
\hline No & Aspek & Indikator & $\begin{array}{c}\text { Jumlah } \\
\text { Butir }\end{array}$ \\
\hline 1 & Media & $\begin{array}{l}\text { a. Kejelasan gambar } \\
\text { b. Kejelasan penggunaan audio } \\
\text { c. Ketepatan ukuran dan jenis huruf } \\
\text { d. Kejelasan animasi }\end{array}$ & 4 \\
\hline 2 & Materi & $\begin{array}{l}\text { a. Penggunaan contoh pada media mempermudah } \\
\text { memahami materi } \\
\text { b. Materi pada animasi mudah dimengerti } \\
\text { c. Penyajian materi sesuai dengan yang dipelajari di } \\
\text { sekolah }\end{array}$ & 3 \\
\hline 3 & Strategi & $\begin{array}{l}\text { a. Media dapat menarik perhatian peserta didik dalam } \\
\text { belajar }\end{array}$ & 1 \\
\hline 4 & Evaluasi & $\begin{array}{l}\text { a. Petunjuk pengerjaan soal jelas } \\
\text { b. Penyajian soal sesuai dengan materi }\end{array}$ & 2 \\
\hline 5 & Manfaat & a. Animasi mempermudah proses pembelajaran & 1 \\
\hline
\end{tabular}

Metode analisis data yang digunakan dalam penelitian pengembangan ini yaitu metode analisis deskriptif kualitatif dan metode analisis deskriptif kuantitatif. (1) Agung (2017:118) mengungkapkan bahwa "metode analisis kualitatif merupakan suatu cara untuk menganalisis data yang dilakukan dengan sistematis dalam bentuk kalimat/kata-kata, kategori tentang objek (benda, gejala, dan variabel tertentu) sehingga mendapatkan kesimpulan umum. Metode analisis kualitatif ini digunakan untuk mengolah data hasil dari uji ahli desain pembelajaran, ahli media pembelajaran, ahli isi pembelajaran, uji coba perorangan, uji coba kelompok kecil. Data yang didapatkan kemudian dikelompokkan berdasarkan masukan, kritik, tanggapan, dan saran yang terdapat pada kuesioner. (2) Metode analisis deskriptif kuantitatif merupakan "suatu cara pengolahan data yang dilakukan dengan cara menyusun secara sistematis dalam bentuk angka-angka dan atau presentasi mengenai suatu objek yang diteliti, sehingga mendapatkan kesimpulan", 
(Agung, 2017:118). Rumus untuk menghitung persentase dari masing-masing subyek adalah sebagai berikut.

$$
\begin{array}{r}
\text { Presentase }=\frac{\sum(\text { jawaban } \times \text { bobot tiap pilihan }}{n \times \text { bobot tertinggi }} \times 100 \% \\
\text { Sumber: Tegeh dan Jampel (2017:99) }
\end{array}
$$

Keterangan:

$\sum=$ jumlah

$\mathrm{n}=$ jumlah seluruh angket

Selanjutnya, untuk menghitung presentase keseluruhan subyek digunakan rumus:

$$
\text { Presentse }=\mathrm{F}: \mathrm{N}
$$

Sumber: Tegeh dan Jampel (2017:99)

Keterangan:

$\mathrm{F}=$ jumlah presentase keseluruhn subyek

$\mathrm{N}=$ banyak subyek

Terkait dengan pemberian makna dan pengambilan keputusan pada animasi dua dimensi digunakan ketetapan sebagai berikut.

Tabel 5. Konversi Tingkat Pencapaian dengan Skala 5

\begin{tabular}{ccc}
\hline Tingkat Pencapaian & Kualifikasi & Keterangan \\
\hline $90 \%-100 \%$ & Sangat baik & Tidak perlu direvisi \\
$75 \%-89 \%$ & Baik & Sedikit revis \\
$65 \%-74 \%$ & Cukup & Direvisi secukupnya \\
$55 \%-64 \%$ & Kurang & Banyak hal yang direvisi \\
$0-54 \%$ & Sangat Kurang & Diulangi membeuat produk \\
\hline \multicolumn{2}{c}{ Sumber: Tegeh dan Jampel (2017:223) }
\end{tabular}

\section{HASIL DAN PEMBAHASAN}

\section{HASIL}

Hasil penelitian pengembangan ini dibahas dua hal pokok, yaitu: (1) mendeskripsikan rancang bangun animasi dua dimensi, dan (2) mendeskripsikan hasil validitas animasi dua dimensi.

Rancang bangun animasi dua dimensi menggunakan lima tahapan model pengembangan ADDIE. Tahap pertama yang dilakukan yaitu tahap analisis. Pada tahap ini dilakukan kegiatan observasi secara menyeluruh, penyebaran kuesioner kepada siswa, dan melakukan wawancara kepada guru kelas sehingga, masalah-masalah yang dihadapi oleh guru dalam kegiatan pembelajaran dan hubungan terhadap ketersedian sarana dan fasilitas pendukung di sekolah atau ketertarkaitan terhadap karakteristik siswa dapat dipecahkan. Tahap analisis yang dilakukan adalah: (1) analisis karakteristik siswa dan masalah pembelajaran, (2) analisis kompetensi, dan (3) analisis fasilitas dan lingkungan.

Tahap kedua yang dilakukan adalah tahap desain. Pada tahap ini terdapat beberapa konsep yang dirancang, yaitu: (1) konsep desain dilakukan untuk menentukan target audience, dan merancang flowchart. (2) Konsep cerita dilakukan untuk merancang storyboard, storyline, dan menentukan durasi. (3) Konsep audio dilakukan untuk menentukan musik latar, sound $f x$, dan pengisi suara/narrator. (4) Konsep visual dilakukan untuk merancang karakter yang terdapat pada animasi dua dimensi. (5) Konsep media 
dilakukan untuk mendesain cover CD (Compact Disk) yang bertujuan untuk menyimpan hasil jadi animasi, dan merancang desain sampul buku panduan penggunaan animasi dua dimensi, dan (6) menyusun instrumen penilaian. Semuanya disiapkan untuk menjadi dasar dan alur dalam tahap pengembangan.

Tahap ketiga yang dilakukan adalah tahap pengembangan. Pada tahap ini kegiatan yang dilakukan yaitu: (1) desain awal animasi dua dimensi yang masih berbentuk flowchart, storyboard dan storyline dikembangkan menjadi sebuah produk yang matang dan siap untuk diimplementasikan. (2) Mengembangkan evaluasi untuk mengetahui pemahaman siswa setelah mempelajari materi yang terdapat pada animasi dua dimensi. Dan (3) merancang buku panduan penggunaan animasi dua dimensi.

Tahap keempat yang dilakukan adalah tahap implementasi. Pada tahap ini kegiatan yang dilakukan yaitu: (1) uji validasi animasi dua dimensi berdasarkan aspek desain pembelajaran oleh ahli desain pembelajaran, (2) uji validasi animasi dua dimensi berdasarkan aspek media pembelajaran oleh ahli media pembelajaran, (3) uji validasi animasi dua dimensi berdasarkan aspek isi pembelajaran oleh ahli isi pembelajaran, (4) uji coba perorangan, dan (5) uji coba kelompok kecil, yang bertujuan untuk mengetahui kelayakan dan kuaitas pembelajaran animasi dua dimensi yang dikembangkan.

Tahap terakhir yang dilakukan yaitu tahap evaluasi. Evaluasi dapat berupa formatif yang bertujuan untuk menilai produk yang telah dikembangkan mencangkup validitas ahli, uji coba perorangan, dan uji coba kelompok kecil. Berdasarkan tahapan tersebut, maka animasi dua dimensi berhasil dikembangkan dengan menggunakan model ADDIE.

Hasil validitas animasi dua dimensi ditentukan berdasarkan hasil review ahli desain pembelajaran, ahli media pembelajaran, ahli isi pembelajaran, uji coba perorangan, dan uji coba kelompok kecil. Adapun hasil validitas animasi dua dimensi, secara lebih rinci dapat disajikan pada tabel 6 .

Tabel 6. Hasil Uji Validitas Produk

\begin{tabular}{clcl} 
No & \multicolumn{1}{c}{ Subjek Uji Coba } & Hasil Validitas & Keterangan \\
\hline 1 & Uji Ahli Desain Pembelajaran & $95 \%$ & Sangat Baik \\
2 & Uji Ahli Media Pembelajaran & $95 \%$ & Sangat Baik \\
3 & Uji Ahli Isi Pembelajaran & $94,5 \%$ & Sangat Baik \\
4 & Uji Coba Perorangan & $91,67 \%$ & Sangat Baik \\
5 & Uji Coba Kelompok Kecil & $94,24 \%$ & Sangat Baik \\
\hline
\end{tabular}

Berdasarkan hasil perolehan data tersebut, dapat disimpulkan bahwa animasi dua dimensi memiliki validitas sangat baik dan layak digunakan untuk membantu siswa belajar pada pembelajaran tematik serta mempermudah guru dalam menyampaikan materi pembelajaran. Melalui hasil uji validitas produk animasi dua dimensi pada ahli desain pembelajaran, ahli media pembelajaran, ahli isi pembelajaran, uji coba perorangan, dan uji coba kelompok kecil diperoleh saran, masukan, dan komentar. Seluruh saran, masukan, dan komentar tersebut menjadi bahan revisi dan sudah ditindaklanjuti demi kesempurnaan produk animasi dua dimensi yang telah dikembangkan. Adapun masukan, saran, dan komentar yang diberikan oleh ahli desain pembelajaran dapat disajikan pada tabel 7 . 
Tabel 7. Perbaikan Produk oleh Ahli Desain Pembelajaran

\begin{tabular}{cll}
\hline No & Saran, Masukan, dan Komentar & \multicolumn{1}{c}{ Revisi } \\
\hline 1. & Pada halaman paling depan, beri & Pada halaman awal, diberi identitas \\
& identitas pengembang., judul, kelas, & pengembang, judul, kelas, semester dan \\
semester, jenjang. & jenjang. \\
2. & $\begin{array}{l}\text { Pada tujuan pembelajaran Tema 5 ada } \\
\text { salah ketik, "sederhan", seharusnya }\end{array}$ & $\begin{array}{l}\text { Menambahkan huruf "a" pada kalimat } \\
\text { sederhana. }\end{array}$ \\
& sederhana.
\end{tabular}

Berdasarkan saran, masukan, dan komentar yang diberikan oleh ahli media pembelajaran, dilakukan revisi dan sudah ditindaklanjuti demi kesempurnaan produk animasi dua dimensi yang telah dikembangkan. Adapun saran, masukan, dan komentar yang diberikan oleh ahli media pembelajaran dapat disajikan pada tabel 8 .

Tabel 8. Perbaikan Produk oleh Ahli Media Pembelajaran

\begin{tabular}{cll}
\hline No & Saran, Masukan, dan Komentar & \multicolumn{1}{c}{ Revisi } \\
\hline 1. Pada saat klik petunjuk belajar agar ada & Pada tampilan petunjuk belajar diberi \\
tombol close agar tidak menggunakan & tombol close. \\
tombol next dan back & \\
2. Pada halaman beranda sajikan menu & Pada halaman beranda diberi tombol- \\
yang dianggap penting, seperti & tombol penting seperti pendahuluan, \\
pendahuluan, materi, evaluasi. & materi, evaluasi dan tombol profil \\
Sedangkan profil pengembangan bisa & pengembang diletakkan pada footer \\
disajikan pada header atau footer. &
\end{tabular}

Berdasarkan saran, masukan, dan komentar yang diberikan oleh ahli isi pembelajaran, dilakukan revisi dan sudah ditindaklanjuti demi kesempurnaan produk animasi dua dimensi yang telah dikembangkan. Adapun saran, masukan, dan komentar yang diberikan oleh ahli isi pembelajaran dapat disajikan pada tabel 9.

Tabel 9. Perbaikan Produk oleh Ahli Isi Pembelajaran

\begin{tabular}{lcl}
\hline No & Saran, Masuka, dan Komentar & \multicolumn{1}{c}{ Revisi } \\
\hline 1. & Volume suara narrator dinaikkan lagi & $\begin{array}{l}\text { Pada animasi dua dimensi, suara narrator } \\
\text { diedit. Volume dari narrator dinaikkan } \\
\text { sedangkan musik latar dikecilkan. }\end{array}$ \\
\hline
\end{tabular}

Adapun hasil pengembangan produk animasi dua dimensi, dapat disajikan dalam gambar 1, 2, 3, dan 4 


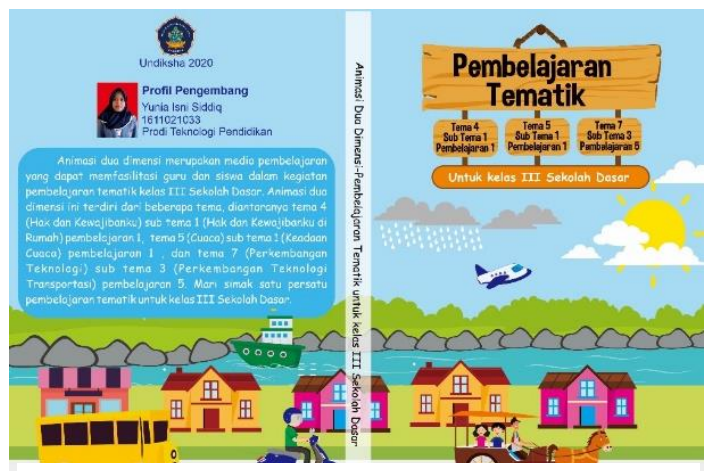

Gambar 1. Cover CD (Compact Disk)

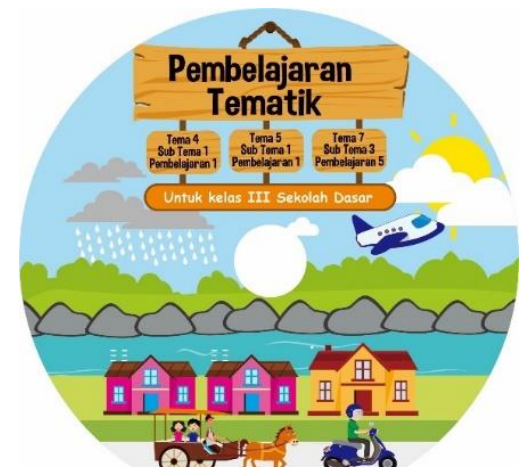

Gambar 2. Label CD (Compact Disk)

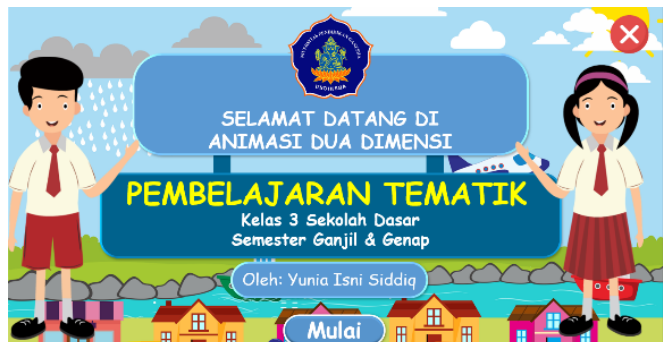

Gambar 3. Tampilan awal

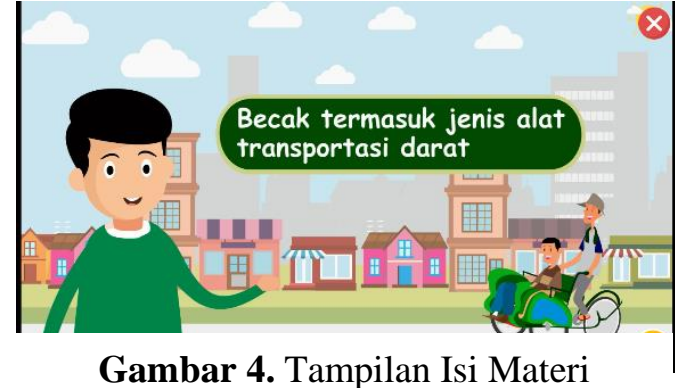

Gambar 4. Tampilan Isi Materi

\section{PEMBAHASAN}

Penelitian ini adalah penelitian pengembangan animasi dua dimensi pada pembelajaran tematik untuk kelas III Sekolah Dasar. Setelah melewati uji review oleh para ahli dan telah melakukan uji coba perorangan dan kelompok kecil, animasi dua dimensi ini memperoleh kualifikasi sangat baik. Adapun kualifikasi sangat baik pada animasi dua dimensi ini dapat terjadi karena hal-hal sebagai berikut.

Proses pengembangan animasi dua dimensi menggunakan model ADDIE, yaitu: (1) analisis (analysis), (2) perencanaan (design), (3) pengembangan (development), (4) implementasi (implementation), dan (5) evaluasi (evaluation). Model ADDIE digunakan karena dalam prosedur atau tahap-tahapan yang dilalui dalam pengembangan animasi dua dimensi ini sangat jelas, mudah, tersistematis, dan sesuai dengan desain pembelajaran yang dikembangkan. Hal ini sesuai dengan pendapat dari Tegeh dan Kirna (2013) yang mengemukakan bahwa model ADDIE merupakan model desain pembelajaran yang paling generik dan dikembangkan secara sistematis dan berpijak pada landasan teoritis desain pembelajaran. Pertimbangan-pertimbangan yang harus diperhatikan dalam menentukan model pengembangan yang digunakan dalam membuat animasi dua dimensi ini diantaranya: (1) model yang dipilih harus sesuai dipahami pengembang, (2) mengandung tahapan yang tidak terlalu rumit dan tidak sederhana, (3) model dapat mengarahkan pengembang untuk membuat program secara aktif (dalam Mahadewi dan Sukmana, 2015).

Terdapat beberapa aspek yang mempengaruhi hasil validitas animasi dua dimensi yang dikembangkan. Aspek tersebut diantaranya, aspek isi pembelajaran, aspek desain pembelajaran, dan aspek media pembelajaran. Ditinjau lebih lanjut pada aspek isi pembelajaran, animasi dua dimensi ini berada pada kualifikasi validitas sangat baik. Kualifikasi validitas sangat baik ini dipengaruhi oleh kesesuaian visual memperjelas materi 
pembelajaran. Hal ini dibuktikan dari hasil penilaian yang diberikan oleh kedua ahli isi pembelajaran pada butir istrumen terkait kesesuaian visual memperjelas materi pembelajaran memperoleh persentase (100\%) dengan kualifikasi sangat baik. Selain itu, penilaian yang diperoleh dari uji coba perorangan dan uji coba kelompok kecil terhadap butir instrumen kesesuaian gambar memperjelas dan mempermudah siswa memahami materi memperoleh $(93,33 \%)$ dengan kriteria sangat baik pada uji coba perorangan, dan kriteria baik $(86,67 \%)$ pada uji coba kelompok kecil. Jadi, dapat disimpulkan bahwa visual dalam animasi dua dimensi dapat memperjelas materi pembelajaran dan mempermudahkan siswa memahami materi pembelajaran, hal ini sejalan dengan pendapat Sudarma, dkk (2015) yang mengungkapkan bahwa deskripsi yang panjang dan abstrak lebih mudah dipahami jika divisualisasikan dengan gambar serta gambar mampu memudahkan orang mengingat pesan. Hal ini juga sesuai dengan hasil penelitian Rosnihayati (2017) yang mengungkapkan bahwa penggunaan gambar dalam pembelajaran dapat mengkonkretkan berbagai konsep materi yang sifatnya abstrak, meningkatkan motivasi, dan meningkatkan hasil belajar siswa.

Kualifikasi sangat baik ini juga diperoleh karena penyajian materi sesuai dengan tuntutan kompetensi dasar, indikator, dan tujuan pembelajaran yang terdapat pada animasi dua dimensi. Hal ini dibuktikan dari hasil penilaian yang diberikan oleh kedua ahli isi pembelajaran pada butir istrumen terkait penyajian materi sesuai dengan tuntutan kompetensi dasar, indikator, dan tujuan pembelajaran yang terdapat pada animasi dua dimensi memperoleh persentase (100\%) dengan kualifikasi sangat baik. Selain itu, penilaian yang diperoleh dari uji coba perorangan dan uji coba kelompok kecil terhadap butir instrumen terkait kesesuaian materi memperoleh (100\%) dengan kriteria sangat baik pada uji coba perorangan, dan kriteria sangat baik $(96,67 \%)$ pada uji coba kelompok kecil. Jadi, dapat disimpulkan bahwa kesesuaian isi pembelajaran dengan tujuan pembelajaran sangat penting dalam pengembangan media untuk meningkatkan kualitas pembelajaran, hal ini sejalan dengan pendapat Arif dan Yanawati (2018) yang mengungkapkan bahwa tujuan yang jelas, dapat menjadi acuan dalam setiap proses pembelajaran yang dilangsungkan.

Berdasarkan aspek desain pembelajaran, animasi dua dimensi ini berada pada validitas sangat baik. Kualifikasi validitas sangat baik ini dipengaruhi karena penggunaan media animasi dua dimensi dapat memicu ketertarikan dan keterlibatan sasaran belajar. Hal ini dibuktikan dari hasil penilaian yang diberikan oleh ahli desain pembelajaran pada butir istrumen terkait memicu ketertarikan dan keterlibatan sasaran belajar menggunakan animasi dua dimensi memperoleh persentase (100\%) dengan kualifikasi sangat baik. Selain itu, penilaian yang diperoleh dari uji coba perorangan dan uji coba kelompok kecil terhadap butir instrumen kesesuaian penggunaan animasi pada media menarik dan mempermudah siswa memahami materi diperoleh $(93,33 \%)$ dengan kriteria sangat baik pada uji coba perorangan, dan kriteria sangat baik (90\%) pada uji coba kelompok kecil. Jadi, dapat disimpulkan bahwa animasi dua dimensi dapat memicu ketertarikan dan keterlibatan sasaran belajar menggunakan animasi dua dimensi serta mempermudah siswa memahami materi, hal ini sesuai dengan pendapat Jadmiko (dalam Nurhayani, 2015) yang mengungkapkan bahwa animasi dapat menyampaikan suatu konsep yang rumit, menarik perhatian, meningkatkan motivasi, dan meransang pemikiran siswa, dapat menyajikan pesan yang lebih baik dibanding dengan media lain, serta dapat digunakan untuk menyediakan pembelajaran secara maya. Hal tersebut sesuai dengan hasil penelitian 
Muslina, dkk (2017) yang mengungkapkan bahwa media pembelajaran animasi terbukti dapat menarik dan meningkatkan minat belajar siswa.

Kualifikasi sangat baik ini juga diperoleh karena terdapat kejelasan judul animasi dan kejelasan sasaran pengguna. Hal ini dibuktikan dari hasil penilaian yang diberikan oleh ahli desain pembelajaran pada butir istrumen terkait kejelasan judul animasi dan kejelasan sasaran pengguna memperoleh persentase (90\%) dengan kualifikasi sangat baik. Kejelasan judul dan sasaran pengguna disetiap media pembelajaran ataupun bahan ajar dapat memberikan informasi awal kepada pengguna tentang isi yang ada di dalamnya dari media ataupun bahan ajar tersebut. Sasaran pengguna yang dimaksud adalah peserta didik. Hal ini selaras dengan pendapat dari Mahadewi dan Sukmana (2015) yang mengemukakan bahwa komponen-komponen dokumen pengembangan produk bervariasi, namun secara standar minimal mengandung: judul produk, kebutuhan pengguna, tujuan pembuatan program, konteks pembuatan program (profil dan lingkungan pengguna), dan deskripsi porduk.

Ditinjau dari aspek media pembelajaran, animasi dua dimensi ini berada pada validitas sangat baik. Validitas sangat baik ini dipengaruhi oleh kejelasan suara narrator, narasi memperjelas/mendukung materi, penggunaan sound effect, dan musik latar. Hal ini dibuktikan dari hasil penilaian yang diberikan oleh ahli media pembelajaran pada butir istrumen terkait kejelasan suara narrator, narasi memperjelas/mendukung materi, penggunaan sound effect, dan musik latar memperoleh persentase $(90 \%)$ dengan kualifikasi sangat baik. Selain itu, penilaian yang diperoleh dari uji coba perorangan dan uji coba kelompok kecil terhadap butir instrumen terkait penggunaan suara jelas dan menarik diperoleh $(93,33 \%)$ dengan kriteria sangat baik pada uji coba perorangan, dan kriteria sangat baik $(96,67 \%)$ pada uji coba kelompok kecil. Jadi, dapat disimpulkan bahwa kejelasan suara narrator, narasi memperjelas/mendukung materi, kesesuaian penggunaan sound effect, dan kesesuaian musik latar dapat mempermudah siswa memahami materi dan mampu menarik perhatian dalam pembelajaran, hal ini sejalan dengan pendapat Sudarma, dkk (2015) yang mengemukakan bahwa suara dalam komunikasi media seperti suara narrator, suara efek, dan suara latar merupakan elemen pendukung kejelasan pesan dalam gambar, video, dan animasi untuk dapat memberikan kesan penekanan, senang, sedih, dan sebagainya. Hal ini juga sesuai dengan hasil penelitian Widyaningrum (2015) yang mengungkapkan bahwa penggunaan audio pada proses pembelajaran dapat meningkatkan kemampuan menyimak siswa, dapat memacu motivasi siswa menjadi lebih perhatian, serius, dan aktif.

Kualifikasi sangat baik ini juga diperoleh karena kemudahan penggunaan dan kelancaran link interaktif. Hal ini dibuktikan dari hasil penilaian yang diberikan oleh ahli media pembelajaran pada butir istrumen terkait kemudahan penggunaan dan kelancaran link interaktif memperoleh persentase (90\%) dengan kualifikasi sangat baik. Kemudahan penggunaan dan kelancaran link interaktif dalam media dapat mempermudah pengguna untuk mengendalikan program dan dapat dengan mudah mengakses materi pembelajaran apa saja yang terdapat pada animasi dua dimensi. Hal ini selaras dengan pendapat Sudarma, dkk (2015) yang mengungkapkan bahwa pengguna memiliki otonomi untuk mengakses seluruh halaman yang terdapat pada media, dan hal ini dapat dilakukan dengan menggunakan link (penghubung) antara halaman satu dengan halaman lainnya. 


\section{SIMPULAN}

Simpulan yang dapat ditarik dari penelitian pengembangan animasi dua dimensi yaitu, pertama, rancang bangun animasi dua dimensi yang dikembangkan mengacu pada model ADDIE, yaitu: (a) tahap analisis (analysisi), (b) tahap perancangan (design), (c) tahap pengembangan (development), (d) tahap implementasi (implementation), dan (e) tahap evaluasi (evaluation). Kedua, berdasarkan pengembangan yang mengacu model ADDIE, animasi dua dimensi pada pembelajaran tematik berhasil mencapai kualifikasi sangat baik pada setiap uji validitas isi pembelajaran, uji validitas desain pembelajaran, uji validitas media pembelajaran, uji coba perorangan, dan uji coba kelompok kecil. Animasi dua dimensi ini layak untuk diterapkan dalam proses pembelajaran sehingga segala permasalahan pembelajaran dapat teratasi dengan baik.

\section{DAFTAR PUSTAKA}

Agung, A. A. G. (2017). Metodologi Penelitian Kuantitatif (Perspektif Manajemen Pendidikan). Singaraja: Universitas Pendidikan Ganesha.

Arif dan Yeniawati. (2018). Pengantar Desain Pembelajaran. Jambi: Pustaka Ma'Arif Press.

Astiningtyas, A. (2018). Kesiapan Guru Sekolah Dasar dalam Pelaksanaan Pembelajaran Tematik Integratif pada Kurikulum 2013. Jurnal Primary Program Studi Pendidikan Guru Sekolah Dasar, 7(1), 60-67.

Awalia, dkk. (2019). Pengembangan Media Pembelajaran Animasi Powtoon pada Mata Pelajaran Matematika di Kelas IV SD. Jurnal Matematika Kreatif-Inovatif, 10(1), 4956.

Aziz, Z. (2019). Fluxus Animasi dan Komunikasi di Era Media Baru Digital. Channel Jurnal Komunikasi, 7(1), 49-58.

Binanto, I. (2010). Multimedia Digital - Dasar Teori dan Pengembangannya. Jakarta: C.V Andi Offset.

Budiman, H. (2017). Peran Teknologi Informasi dan Komunikasi dalam Pendidikan. AlTadzkiyyah: Jurnal Pendidikan Islam, 8(1), 31-43.

Herlyani, E. (2014). Animasi Dua Dimensi. Yogyakarta: Graha Ilmu.

Jembari, dkk. (2015). Pengembangan Video Animasi Dua Dimensi dengan Model Waterfall pada Pembelajaran IPS Kelas VIII. Jurnal Edutech Universitas Pendidikan Ganesha, 3(1).

Kasih, F. R. (2017). Pengembangan Film Animasi dalam Pembelajaran Fisika pada Materi Kesetimbangan Benda Tegar di SMA. Tadris: Jurnal Keguruan Dan Ilmu Tarbiyah, $2(1), 41-47$.

Kustandi dan Darmawan. (2020). Pengembangan Media Pembelajaran (Konsep \& Aplikasi Pengembangan Media Pembelajaran bagi Pendidik di Sekolah dan Masyarakat). Jakarta: Kencana.

Mahadewi dan Sukmana. (2015). Text-Based Programming: Konsep Dasar \& Aplikasi Pengembangan Produk Pendidikan. Yogyakarta: Graha Ilmu.

Mastur. (2017). Implementasi Kurikulum 2013 dalam Pelaksanaan Pembelajaran di SMP. Jurnal Inovasi Teknologi Pendidikan, 4(1). 
Muslina, dkk. (2017). Kelayakan Media Animasi Hukum Newton II Tentang Gerak Pada Bidang Miring dan Katrol di SMA Kabupaten Aceh Besar. Jurnal IPA Dan Pembelajaran IPA (JIPI), 1(1), 64-72.

Muzakki dan Manan. (2016). Pengembangan Media Animasi Pembelajaran Interaktif Pokok Bahasan Gaya pada Mata Pelajaran IPA Kelas IV SD. Edcomtech Jurnal Kajian Teknologi Pendidikan, 1(2), 147-152.

Nurhayani, D. (2015). Pengaruh Media Animasi Terhadap Hasil Belajar Konsep Sistem Peredaran Darah Manusia Siswa Kelas VIII MTs Raudhatul Jannah Palangkaraya. EduSains, 3(2), 125-140.

Prameswari, N. K. (2017). Pengembangan Media Animasi Berbasis Kooperatif Tipe STAD untuk Pembelajaran Tematik pada Kemampuan Berfikir Kritis Siswa Sekolah Dasar. Pinus, 2(1), 61-72.

Prastowo, A. (2014). Bahan Ajar Tematik. Jakarta: Kencana Media Group.

Pratama, dkk. (2020). Pengembangan Video Animasi Budaya Reog Porogo sebagai Suplemen Kegiatan Ekstrakulikuler Siswa Sekolah Dasar. JINOTEP (Jurnal Inovasi Teknologi Pembelajaran), 7(1), 9-17.

Pratiwi dan Widagdo. (2017). Implementasi Pembelajaran Tematik pada Kelas Awal di Sekolah Dasar. Joyful Learning Journal, 6(4), 277-284.

Rosmiati, M. (2019). Animasi Interaktif Sebagai Media Pembelajaran Bahasa Inggris Menggunakan Metode ADDIE. Paradigma: Jurnal Komputer Dan Informatika Univiersitas Bina Sarana Informatika, 21(2).

Rosnihayati. (2017). Penggunaan Media Gambar untuk Meningkatkan Hasil Belajar IPS Siswa Kelas II SDN 003 Pagaran Tapah Darussalam Kabupaten Rokan Hulu. Primary: Jurnal Pendidikan Guru Sekolah Dasar, 6(1), 306-313.

Sanjaya, W. (2015). Perencanaan dan Desain Sistem Pembelajaran. Jakarta: Prenadamedia Group.

Suartama, I. K. (2017). Animasi Pembelajaran Konsep dan Pengembangannya. Singaraja: Fakultas Ilmu Pendidikan, Universitas Pendidikan Ganesha.

Sudarma, dkk. (2015). Desain Pesan Kajian Analisis Desain Visual Teks dan Image. Yogyakarta: Graha Ilmu.

Sudatha dan Tegeh. (2015). Desain Multimedia Pembelajaran. Yogyakarta: Mediaakademi.

Tegeh dan Jampel. (2017). Metode Penelitian Pengembangan. Singaraja: Universitas Pendidikan Ganesha.

Tegeh dan Kirna. (2013). Pengembangan Bahan Anjar Metode Penelitian Pendidikan dengan ADDIE Model. Jurnal Ikatan Alumni (IKA) Universitas Pendidikan Ganesha, $11(1)$

Wahyuni, dkk. (2018). Pengaruh Penggunaan Media Animasi pada Materi Larutan Elektrilit dan Nonelektrolit terhadap Kemampuan Berfikir Kritis Siswa SMA. JIPI (Jurnal IPA Dan Pembelejaran IPS), 2(21-28).

Widjayanti, dkk. (2019). Media Pembelajaran Interaktif Berbasis Animasi pada Materi Statistika untuk Siswa Kelas 7 SMP. Jurnal Pendidikan Matemati, 13(1), 101-112. 
Widyaningrum, H. K. (2015). Penggunaan Media Audio untuk Meningkatkan Kemampuan Menyimak Dongeng Anak pada Siswa Kelas IV Sekolah Dasar. Premiere Educandum, 5(2).

Yogiyatno dan Soyan. (2013). Pengembangan Multimedia Interaktif Kompetensi Dasar Mengoperasikan Software Basis Data untuk SMK Negeri 1 Seyegan. Jurnal Pendidikan Vokasi, 3(391-404). 